\title{
Inhibiting Factors Affecting Teachers' Implementation of the KBSM (Revised) English Language Curriculum
}

\section{HAMIDA BEE BI ABDUL KARIM}

Universiti Utara Malaysia

\begin{abstract}
This paper aims to discuss teachers' degree of implementation of the KBSM (Revised) English Language Curriculum, introduced in 2003. It also sets to highlight the inbibiting factors that had impeded teachers' implementation of the Skills Specifications or activities suggested in the Huraian Sukatan Pelajaran (HSP) Bahasa Inggeris Tingkatan Empat of the new curriculum. Firstly, the author finds that about 60 percent of the teachers obtained only a medium degree of implementation for 18 out of the 22 Skills Specifications. Secondly, the author concludes that among the prominent factors that had inhibited teachers' implementation of the KBSM (Revised) English language curriculum in Malaysian classrooms were too many components of the new curriculum, bence leading to lack of understanding of the curriculum, lack of in-service training, time constraints and finally inadequate and irrelevant teaching materials.
\end{abstract}

\section{INTRODUCTION}

As the main agent of curriculum change, teachers are expected to play important roles in the different phases of a curriculum change process, i.e., the initiation, implementation and continuation phases (Fullan, 1991; 2000). However, this paper will only look into the second phase of the curriculum change process, i.e., the implementation phase. This phase is normally perceived as the most significant in determining the success (or failure) of a curriculum change project since it specifically calls for teachers' full participation and commitment (Fullan, 1991).

Teachers' involvement in a curriculum change process may occur at different levels such as the national, state, district, school, and lastly the classroom levels (Anna Christina, 1989). However, this paper will focus on the classroom level only since this is where 
the teachers play their most important role in the curriculum change process. The study conducted looked into the teachers' degree of implementation solely from the teachers' perceptions since the curriculum had just been implemented for a period of ten months (January till October 2003). As such, at the time the study was conducted, the author felt that it was too early to seek the views of others such as the curriculum officers, principals, parents or even students.

\section{Curriculum Changes in Malaysia since Independence}

The literature shows that changes in the English language curriculum increased after Malaysia gained her independence in 1957. Many important issues were raised during that time such as the variety of English that should be taught, and the cultural forms and contexts that should be included in the syllabus. All these took place due to two main reasons. The first was the strong nationalist sentiments that prevailed at that time. The second was the politicians' influential role in moulding the English language curriculum, i.e., to limit the status of English as only a compulsory subject instead of as a medium of instruction in both primary and secondary schools (Solomon, 1988).

The implementation of the Kurikulum Baru Sekolah Rendah (KBSR) in 1982 and the Kurikulum Bersepadu Sekolah Menengah (KBSM) in 1988 inevitably led to the introduction of two new English Language syllabuses, known as the KBSR English Language Syllabus and the KBSM English Language Syllabus. Basically, the KBSR and KBSM are skills-based syllabuses advocating the communicative approach to English language teaching (Rajaretnam \& Nalliah, 1999). The emphasis is on the acquisition of the four language skills of listening, speaking, reading, writing and also the enhancement of communicative ability.

The most current change in the English language curriculum in the secondary schools is the KBSM (Revised) English Language Curriculum. This curriculum was first introduced into Form One and Form Four in 2003. There is a shift in focus compared to the previous KBSM English Language Syllabus (Kementerian Pendidikan Malaysia, 2003). The main feature of this new curriculum is that instead of just highlighting the four skills, i.e., listening, speaking, reading and writing, it also pays attention to communication skills.

As such, the new English language curriculum is organized in a manner that reflects the way English is actually used in society in 
everyday life (Kementerian Pendidikan Malaysia, 2002). The English syllabus at the secondary level specifies the content to be taught in Form One and Form Four, and they are divided into three main sections:

1. The Learning Outcomes that specify the skills to be achieved by the students in the three main areas of language use, i.e. the Interpersonal, the Informational and the Aesthetic. These areas incorporate the integration of the four language skills of listening, speaking, reading and writing.

2. The Language Content that outlines the grammar, the sound system and the word list to be incorporated into the lessons in the classroom.

3. The Educational Emphases that incorporate global developments in education such as ICT skills, thinking skills and the Multiple Intelligence theory. All these should be utilized and woven into activities and teaching materials used in the classroom.

\section{The Form Four KBSM (Revised) English Language Curriculum Specifications}

The syllabuses of the KBSM (Revised) English Language Curriculum are further detailed out in the Curriculum Specifications. These are actually separate documents prepared for each year of the secondary school, known as the Huraian Sukatan Pelajaran (Kementerian Pendidikan Malaysia, 2003). Each document serves as a guide to the teachers in terms of the skills that students should achieve by the end of the year, the topics or themes to be covered in class, and also the vocabulary, grammar items and the sound system to be taught to students.

The Curriculum Specifications for Form Four are made up of three main sections, i.e. the Learning Outcomes and Specifications, the Language Content and the Educational Emphases. However, this paper will only look into the first section since it forms the main focus of the English language or the Huraian Sukatan Pelajaran Bahasa Inggeris Tingkatan Empat and contains the Learning Outcomes and Skills Specifications to be achieved by students by the end of Form Four. These Skills Specifications are as detailed out in Section I of the Form Four Curriculum Specifications or the Huraian Sukatan Pelajaran Bahasa Inggeris Tingkatan 4 (Kementerian Pendidikan Malaysia, 2003). 


\section{The Learning Outcomes and Skills Specifications}

This part of the English Language syllabus is in turn made up of three main sections and they are presented in three columns in the reference booklet:

\section{Column 1}

This is entitled the Learning Outcomes and consists of the final outcomes related to the skills to be achieved by learners by the end of the year. The Learning Outcomes are spelled out under the three main areas of language use, Interpersonal Use, Informational Use and Aesthetic Use.

Language for Interpersonal Use aims to enable students to establish and maintain friendships and to collaborate with people in doing certain things. There are a total of 22 skills in this area. Language for Informational Use aims to enable students to use English language to obtain, process and give information, while Language for Aesthetic Use aims to provide students with the skills necessary to enjoy literary texts at a level suited to their language proficiency and develop in them the ability to express themselves creatively.

However, it should be noted that this study only focussed on the Skills Specifications of Language for Interpersonal Use since it was perceived as the most important and difficult to teach by a majority of teachers interviewed. In fact, some of them confessed that this area was the most problematic for them as well as the students.

\section{Column 2}

This is termed as the Skills Specifications, and it sets out in detail the skills to be achieved by students in Form Four. The skills specifications are the focus of the questionnaire in this study. This column breaks down the larger outcomes in Column 1 into more manageable skills and sub-skills for teaching and learning. The skills have been set out into three levels ranging from the more basic to the more advanced levels. More specifically, Level 1 spells out the basic skills to be achieved by all learners, regardless of their proficiency level. After completing the tasks in Level 1, teachers may then proceed to the activities in LEVEL 2, and eventually to LEVEL 3. However, teachers should be aware that not all learners should or could progress to LEVEL 3, particularly the slower ones. 
More importantly, the teachers should attempt, at least, to bring a majority of students up to LEVEL 2 (Kementerian Pendidikan Malaysia, 2003).

\section{Column 3}

This column is prepared to assist teachers and is entitled Examples/ Activities/Notes. It contains the teaching points, examples of activities that should be carried out, and certain explanations to direct teachers on how to achieve the intended Learning Outcomes. However, teachers are cautioned that they should not depend on the examples provided in the Curriculum Specifications only. They should "use their initiative, imagination and creativity to extend the experiences of their learners, to reinforce what has been learnt and to create challenging language tasks" (Kementerian Pendidikan Malaysia, 2003, pp. 2). This means that teachers should use their own ideas and materials for teaching to supplement those provided by the authorities such as the Curriculum Development Centre.

\section{Problems Related to the Implementation of a New Curriculum}

In a centrally based education system such as Malaysia, there are bound to be various problems in the implementation phase of a curriculum change process. According to McNeil (1977), one of the main problems faced by curriculum developers at the national level is ensuring that teachers actually use the "products" as they had been intended to in their respective schools. The implementation of curriculum change is also proven to be problematic by Goodlad (1979), who discovered that many teachers failed to carry out effectively the new curriculum given to them, as they did not have clear-cut ideas as to what was actually expected of them in order to implement the proposed changes in their classrooms. To make matters worse, many teachers are not aware of the major factors that "affect their implementation, which in turn affect the extent of their implementation (or continuation) of the change" (Fullan, 1982, p. 55).

In the local context, many shortfalls have been observed in studies conducted on classroom teaching and assessment procedures. The first is the teachers' low (or lack of) understanding of the new curriculum since they played a minimal role in planning it. In Malaysia, teachers are treated as passive implementers of any curriculum changes or innovations that have been determined by the authorities at the 
national level (Khatijah, 1989). As such, they have very little or no say at all in the planning and designing of a new curriculum that they are ultimately responsible for implementing. An example is the switch to English as the medium of instruction for the teaching of mathematics and science, which is regarded by teachers as an abrupt move (Pandian $\&$ Ramiah, 2002). Teachers themselves have expressed the view that they would like to play a more active role in the curriculum development process (Anna Christina, 1989). It can be concluded here that Malaysian teachers would like to be more proactive and involved in planning and designing a curriculum, and not just be mere implementers of it.

Goodlad (1979) and Fullan (1991) assert the importance of teachers' active role in curriculum development to ensure that they really understand what they are expected to carry out in the classrooms. In her study, Hannah Danesvari (1995) implies that the lack of teachers' involvement in curriculum development and revision has led to their inability to effectively implement the proposed changes. This scenario is also reflected in Orland-Barak, Kemp, Ben-Or \& Levi's study (2004) which suggests the importance of teachers playing the role of curriculum developers which could maximize their actual implementation in the classroom. Issa Meyes' study (1994) also confirms this notion when a majority of the teachers recorded only a mediocre degree of implementation of a newly introduced curriculum on a ruralization program in Mali. Thus, it can be summed from all the findings that the success of curriculum changes greatly depends on what the teachers understand in the initial stages of a curriculum development and ultimately carry out in the classroom.

Noor Azmi (1988) concluded that the teachers' degree of implementation of the KBSR was generally low due to lack of guidance and supervision of their work by the authorities concerned. Training is vital in ensuring that teachers get the appropriate language support to enable them to effectively (Cheng, 1994; Pandian \& Ramiah, 2000). Agrawal (2004) asserts the importance of teachers' role and in-service training when she claimed that they were among the factors that had facilitated the teaching of listening, speaking, reading and writing skills in the English language classroom. All these go to show that it is very important for the authorities concerned to increase competence among teachers in order to ensure effective implementation of a curriculum. 
Suaidi (1995) and Punitha Vathy (1998) conclude that although teachers have accepted the Kurikulum Baru Sekolah Rendah (KBSR), they still faced difficulties such as over-sized classes and having to carry out too many learning activities. Issa Meyes (1994) also attributed teachers' failure to carry out many of the activities recommended in the program to time constraints and the fact that teachers had too many activities to be carried out. In addition, teachers may lack opportunities and competence to plan lessons and activities properly for their pupils (Cheng, 1994).

Another problem that has been identified in the Malaysian context is the inadequate amount of teaching materials made available to teachers (Noor Azmi, 1988). The problem seems to persist, as is reflected in the recent findings of Tengku Zawawi's study (2004) on the use and integration of computers in the mathematics curriculum. Adamson (2003) asserts that a good curriculum requires, among others, a blend of suitable teaching materials (basically in the form of innovative textbooks), a variety of pedagogical approaches and a structured training programme.

The above discussion suggests that teachers in Malaysia have faced various in implementing the KBSR and KBSM curriculums, and they continue to face do so. It also highlights the importance of increasing competence among teachers to ensure effective implementation of a curriculum. Among others, teachers should be provided with appropriate skills and know-how to use a curriculum in the classroom, relevant and adequate teaching and learning materials, and also well-planned and organized in-service training on a regular basis.

\section{Objectives of the Study}

Teachers are the main agents of curriculum implementation, especially in the case of a newly introduced one. Thus, the success, (or failure) of the new curriculum is very much in the hands of teachers. Therefore, there is an urgent need for more studies to look into problems Malaysian teachers are facing in implementing a curriculum, particularly a new one. The purpose is to highlight these problems to all parties concerned, especially the authorities, parents and also to the teachers themselves. Ultimately, it is hoped that the authorities can take appropriate measures to overcome these problems, and thus assist teachers in their implementation of the curriculum. 
Firstly, this study sets to determine how far the teachers perceived to have carried out the newly adopted curriculum changes in their classrooms. This is done by assessing the teachers' degree of implementation of the Skills Specifications laid out in the Huraian Sukatan Pelajaran Bahasa Inggeris Tingkatan Empat (Kementerian Pendidikan Malaysia, 2003). Secondly, this study sets to highlight the teachers' perceptions of the inhibiting factors that have impeded their efforts in implementing this new curriculum.

In line with the above objectives, this paper sets to answer the following research questions:

1. What are the teachers' perceptions of their degree of implementation of the Skills Specifications as outlined in the Huraian Sukatan Pelajaran Bahasa Inggeris Tingkatan Empat?

2. What are the inhibiting factors that have impeded the teachers' implementation of the KBSM (Revised) English Language Curriculum in the classroom?

\section{METHODOLOGY}

\section{Sampling}

Although the new English language curriculum was launched for use throughout the nation, this study only looked into its implementation in the state of Kedah. Altogether, there were a total of 75 schools that took part in this study. One important consideration in selecting the sample schools was that they must offer Form Four classes. This pre-condition was important because the focus of this study is on the implementation of the new English language curriculum in Form Four only.

The stratified random sampling method was employed and a total of 203 teachers had been identified as the sample of this study. This number was deemed adequate since a number lesser than this may invite validity and reliability problems, especially if many of the teachers do not respond to the questionnaires distributed. One limitation related to sampling was that although there were many English teachers in each school, only an average of two or three teachers were involved in teaching Form Four classes in each of the 75 schools involved in this study. 


\section{Instrumentation}

The specific research tools used in this study were the questionnaire and interview. The questionnaire was chosen as the main instrument of this study since it would produce a broad database across a large population (Neuman, 1997). This is in line with the first objective of the study i.e. to obtain a global picture of the teachers' perceptions of their degree of implementation of the new English language curriculum.

The face-to-face interview method was used as the second instrument to generate more data and to corroborate the data gathered from the previously conducted questionnaire (Merriam, 1990). The purpose was to elicit further information from teachers, particularly regarding the second objective of this study, i.e. factors that had inhibited their implementation of the new English language curriculum. The interview questions were therefore an extension of the questionnaire. The format used was the semi-structured interview to provide teachers with more opportunity and freedom to express their opinions and experience (Borg and Gall, 1989).

\section{The Questionnaire}

It should be noted that the questionnaire used in this study had been adapted from Issa Meyes' (1994) study. However, it had been adapted to suit the local situations and respondents of this study, and was pilot-tested to further ascertain the suitability of the items as well as their validity and reliability. Firstly, expert judgment of a few curriculum experts were sought to ascertain the overall validity of the questionnaire. Secondly, to ensure the reliability and consistency of teachers' responses, three items from the questionnaire were randomly selected (Items No. 3, No. 6 and No. 12), worded differently and included in the questionnaire as Items No. 23, No. 24 and No. 25. The teachers' scores for the three items (No. 3, No. 6 and No. 12) were correlated to the last three items respectively. The Pearson Correlation test of significance showed significant results of $0.027,0.036$ and 0.025 (correlation was significant at the 0.05 level), indicating that the items in the questionnaire had high reliability and consistency.

The questionnaire consists of questions related to the first objective of the study, i.e. to determine the teachers' perceptions of their degree of implementation of the new English language curriculum. It was based on the 22 Skills Specifications for the first 
Learning Outcome of the new curriculum, i.e. Language for Interpersonal Use. These Skills Specifications are as detailed out in Section I of the Form Four Curriculum Specifications or the Huraian Sukatan Pelajaran Bahasa Inggeris Tingkatan 4 (Kementerian Pendidikan Malaysia, 2003). Teachers were required to respond to the questionnaire by stating whether they had implemented all the 22 Skills Specifications under the Language for Interpersonal Use.

The questionnaire required teachers to state whether they had implemented all the activities listed down for each of the 22 Skills Specifications as specified in the Huraian Sukatan Pelajaran Bahasa Inggeris Tingkatan Empat 2003. Five specific activities were listed down for each Skills Specification, labeled as (a) to (e). A sixth option labeled as (f) - "Others" - was provided to allow teachers to include other activities they had carried out in their classes that were not listed in the (a) to (e) options.

The teachers' responses in the questionnaire were measured on a three-point scale, ranging from 1 to 3 . This scale was adapted from Issa Meyes' (1994) study. If a teacher ticked 0 to 1 activity, he or she was awarded 1 point. A teacher who ticked 2 or 3 activities was awarded 2 points, and finally teachers who ticked 4 activities and above were awarded a full 3 points. Since there was a total of 22 Skills Specifications, the highest possible score a teacher could obtain was 66 points, while the lowest possible score was 0 point.

\section{The Interview}

The interview method was used to probe into the teachers' views and opinions regarding the factors that had inhibited the teachers' implementation of the new English language curriculum. This face-toface interview was to provide deep, rather than broad set of knowledge about a particular phenomenon or problem since teachers could be more explicit in expressing their views regarding the problems they face in implementing the new curriculum (Neuman, 1997; Borg \& Gall, 2002).

However, it was not possible for the researcher to interview all the respondents of this study, mainly due to time constraint. The descriptive data obtained from the questionnaire administered earlier had categorized the teachers into three groups, based on their degree of implementation. Hence the teachers were categorized into three groups, i.e. those with a high degree of implementation, a medium 
degree of implementation, and a low degree of implementation of the new English language curriculum.

All in all, 35 teachers were interviewed. They were randomly selected from each of the three degrees of implementation they belonged to. Since there was the most number of teachers with medium degree of implementation, about 10 percent of them or 15 in number were short-listed for interviewing. However, the number of teachers with low and high degrees of implementation groups was quite small i.e. only 30 and 25 teachers respectively. Therefore, ten teachers were randomly selected from each of the two groups. All the teachers identified were requested to fill up a consent form, thereby indicating their willingness to participate in study. They were also given the assurance that all their responses would be treated with the strictest confidence.

The interview was conducted mainly for the purpose of answering the second question of the study, i.e. What are the inhibiting factors that had impeded their implementation of the KBSM (Revised) English Language Curriculum? Thirty-five teachers were randomly selected for the interview. Seven of them were interviewed individually while the rest were interviewed in several groups (based on their convenience and the situation in the schools). In the discussions that followed, the teachers interviewed individually were referred to as Teachers $1,2,3,4,5,6$ and 7 . Meanwhile, the other 28 teachers were interviewed in eight groups, and they were referred to as Group A (3 teachers), Group B (5 teachers), Group C (4 teachers), Group D (2 teachers), Group E (3 teachers), Group F (5 teachers), Group G (4 teachers), and Group H (2 teachers).

The interview was conducted based on some general questions prepared in the Teacher Interview Schedule. Further details or information were elicited from the teachers as the need arose. The researcher had set interview sessions with all the teachers involved, which were scheduled based on their convenience. There was no fixed time allotted for interviewing each teacher. The researcher personally conducted all the interview sessions, and most of them were taperecorded. In a few cases where the teachers felt less comfortable in the presence of the tape recorder, notes were instead taken by the researcher. All the data gathered were transcribed and analyzed as soon as each interview was over to prevent loss of important data. 


\section{Analysis of Data}

Two types of data analysis were conducted since the study employed two types of data gathering instruments.

\section{Analysis of the Questionnaire}

The set of data obtained via the questionnaire required the quantitative type of analysis. The teachers' responses to the questionnaires were analyzed using the SPSS 10.0 package, and the data analysis involved were the frequencies and percentages. The purpose was to analyze the teachers' responses regarding their implementation practices of the new English language curriculum.

As mentioned earlier, firstly the teachers' responses were measured on a three-point scale. Next, the teachers' perceived degree of implementation was determined by adding up their total scores for all the 22 Skills Specifications. This scoring system was adapted from Issa Meyes' (1994) study. If a teacher's total score was 22 points and below, he or she was designated as having a low degree of implementation. A total score of 23 to 44 points was designated as having a medium degree of implementation, while a total score of 45 points and above was considered as having a high degree of implementation.

\section{Analysis of the Interview}

The second instrument used, i.e., the interview required the qualitative type of analysis. In analyzing the interview data, all the taped interviews were personally transcribed by the researcher as soon as the interview was over. This was to maintain the originality of the data collected and to ensure the accuracy of the transcription. In some cases where the interviews were not taped, the notes made during the interviews were rewritten as accurately and in the actual words used by the respondents during the interviews. This process was also conducted and completed as soon as the interview was over to prevent loss of important data.

The type of data obtained from these interviews was mostly informational. Therefore, the interpretations of these data were mostly subjective and impressionistic in nature. To analyze all the qualitative data, firstly all the teachers' responses during the interviews were grouped into different categories under several headings. Next, these data were analyzed and arranged into some common structures according to the frequencies of their occurrences. Finally, all the data were interpreted to establish some patterns and trends based on the teachers' responses. 


\section{RESULTS AND DISCUSSION}

This part sets to present the results and discuss the findings of this study in relation to the two research questions.

\section{Teachers' Perceived Degree of Implementation of the KBSM (Revised) English Language Curriculum}

This part of the discussion sets to answer the first question of the study, i.e., What are the teachers' perceptions of their implementation of the Skills Specification of the KBSM (Revised) English Language Curriculum? The discussion is sub-divided into two parts. The first is an overall discussion of the teachers' implementation of all the 22 Skills Specifications, followed by a discussion of the teachers' degree of implementation of activities for each Skills Specification of the Form Four English language curriculum.

\section{Teachers' Overall Degree of Implementation of ALL 22 Skills Specifications}

Table 1 depicts the teachers' overall degree of implementation of the activities recommended for all the 22 Skills Specifications. It was found to be only of mid-level, with 72.9 percent of them recording medium degree of implementation. This means that most of the teachers recorded having carried out only two or three out of the six activities suggested for a majority of the Skills Specifications. This was followed by 14.8 percent of them recording low degree of implementation, which means that these teachers had carried out only one or no activity at all for some of the Skills Specifications. Only 12.3 percent of the teachers recorded high degree of implementation, which meant that the teachers had carried out at least four or more activities for some of the Skills Specifications.

Table 1. Teachers' Degree of Implementation of All Skills Specifications

Degree of Implementation

Skills Specifications

\begin{tabular}{llll} 
& Low & Medium & High \\
\hline All Skills Specifications & 30 & 148 & 25 \\
No. 01 - No. 22) & $(14.8 \%)(72.9 \%)$ & $(12.3 \%)$ \\
\hline
\end{tabular}




\section{Teachers' Degree of Implementation of Individual Skills Specification}

From Table 2, it can be summarized that a majority of the teachers recorded the highest percentages for medium degrees of implementation for 18 out of the 22 Skills Specifications. However, a majority of the teachers were found to have recorded high for only two out of the 22 Skills Specifications. The first was Skills Specification No. 1 (Talking and sharing information with others) whereby $47.3 \%$ of the teachers recorded high, while $52.7 \%$ of them recorded high for Skills Specifications No. 8 (Expressing concern in simple English). On the contrary, there were two Skills Specifications which most of the teachers obtained low degrees of implementation. The first was Skills Specifications No. 4 (Keeping a journal of daily activities) whereby only $12.8 \%$ recorded high implementation, followed by $19.7 \%$ of them recording high for Skills Specification No. 5 (Listening and discriminating between sounds).

Table 2. Teachers' Implementation of Activities for Skills Specifications 01 - 22

Skills Specifications

Degree of Implementation

\begin{tabular}{lccc}
\cline { 2 - 4 } & Low & Medium & High \\
\hline $\begin{array}{lcc}\text { 01. Talking and sharing } \\
\text { information with others. }\end{array}$ & $\begin{array}{c}22 \\
(10.8 \%)\end{array}$ & $\begin{array}{c}85 \\
(41.9 \%)\end{array}$ & $\begin{array}{c}96 \\
(47.3 \%)\end{array}$ \\
\hline 02. Responding to questions & 22 & 100 & 81 \\
& $(10.8 \%)$ & $(49.3 \%)$ & $(39.9 \%)$ \\
\hline 03. Relating personal & 22 & 96 & 85 \\
experiences. & $(10.8 \%)$ & $(47.3 \%)$ & $(41.9 \%)$ \\
\hline
\end{tabular}

04. Keeping a journal of daily activities.

05. Listening and

$(57.6 \%)$

$(29.6 \%)$

26

$(12.8 \%)$

80

discriminating between sounds

$(40.9 \%)$

$(39.4 \%)$

$(19.7 \%)$

06.Agreeing/ disagreeing

politely.

26

$(12.8 \%)$

104
$(51.2 \%)$

73

07. Offering advice in

38

(18.7)

101

$(49.8 \%)$

simple language. 


\begin{tabular}{|c|c|c|c|}
\hline $\begin{array}{l}\text { 08. Expressing concern in } \\
\text { simple language. }\end{array}$ & $\begin{array}{c}31 \\
(15.3 \%)\end{array}$ & $\begin{array}{c}65 \\
(32.0 \%)\end{array}$ & $\begin{array}{c}107 \\
(52.7 \%)\end{array}$ \\
\hline $\begin{array}{l}\text { 09. Persuading someone } \\
\text { in simple language. }\end{array}$ & $\begin{array}{c}37 \\
(18.2 \%)\end{array}$ & $\begin{array}{c}112 \\
(55.2 \%)\end{array}$ & $\begin{array}{c}54 \\
(26.6 \%)\end{array}$ \\
\hline $\begin{array}{l}\text { 10. Making inquiries } \\
\text { in simple language. }\end{array}$ & $\begin{array}{c}40 \\
(19.7 \%)\end{array}$ & $\begin{array}{c}120 \\
(59.1 \%)\end{array}$ & $\begin{array}{c}43 \\
(21.2 \%)\end{array}$ \\
\hline $\begin{array}{l}\text { 11. Pronouncing words, } \\
\text { asking questions and } \\
\text { making statements. }\end{array}$ & $\begin{array}{c}59 \\
(29.1 \%)\end{array}$ & $\begin{array}{l}100 \\
(49.3 \%)\end{array}$ & $\begin{array}{c}44 \\
(21.7 \%)\end{array}$ \\
\hline $\begin{array}{l}\text { 12. Read current topics and } \\
\text { exchange ideas. }\end{array}$ & $\begin{array}{c}48 \\
(23.1 \%)\end{array}$ & $\begin{array}{l}124 \\
(61.1 \%)\end{array}$ & $\begin{array}{c}31 \\
(15.3 \%)\end{array}$ \\
\hline $\begin{array}{l}\text { 13. Carrying on conversations } \\
\text { with people. }\end{array}$ & $\begin{array}{c}25 \\
(12.3 \%)\end{array}$ & $\begin{array}{c}112 \\
(55.2 \%)\end{array}$ & $\begin{array}{c}66 \\
(32.5 \%)\end{array}$ \\
\hline $\begin{array}{l}\text { 14. Making decisions regarding } \\
\text { actions to be taken. }\end{array}$ & $\begin{array}{c}52 \\
(25.6 \%)\end{array}$ & $\begin{array}{c}101 \\
(49.8 \%)\end{array}$ & $\begin{array}{c}50 \\
(24.6 \%)\end{array}$ \\
\hline $\begin{array}{l}\text { 15. Making enquiries, } \\
\text { comparisons and decisions } \\
\text { about a product. }\end{array}$ & $\begin{array}{c}40 \\
(19.7 \%)\end{array}$ & $\begin{array}{c}109 \\
(53.7 \%)\end{array}$ & $\begin{array}{c}54 \\
(26.6 \%)\end{array}$ \\
\hline $\begin{array}{l}\text { 16. Placing an order for a } \\
\text { product orally and in writing. }\end{array}$ & $\begin{array}{c}46 \\
(22.2 \%)\end{array}$ & $\begin{array}{c}108 \\
(53.5 \%)\end{array}$ & $\begin{array}{c}49 \\
(24.3 \%)\end{array}$ \\
\hline $\begin{array}{l}\text { 17. Giving feedback/making a } \\
\text { complaint about a product. }\end{array}$ & $\begin{array}{c}31 \\
(15.3 \%)\end{array}$ & $\begin{array}{c}131 \\
(64.5 \%)\end{array}$ & $\begin{array}{c}41 \\
(20.2 \%)\end{array}$ \\
\hline $\begin{array}{l}\text { 18. Reading articles and giving } \\
\text { opinions. }\end{array}$ & $\begin{array}{c}40 \\
(19.7 \%)\end{array}$ & $\begin{array}{c}124 \\
(61.1 \%)\end{array}$ & $\begin{array}{c}39 \\
(19.2 \%)\end{array}$ \\
\hline $\begin{array}{l}\text { 19. Suggesting ways to solve a } \\
\text { problem. }\end{array}$ & $\begin{array}{c}59 \\
(29.1 \%)\end{array}$ & $\begin{array}{c}108 \\
(53.2 \%)\end{array}$ & $\begin{array}{c}36 \\
(17.7 \%)\end{array}$ \\
\hline $\begin{array}{l}\text { 20. Initiating and keeping a } \\
\text { conversation going. }\end{array}$ & $\begin{array}{c}55 \\
(27.1 \%)\end{array}$ & $\begin{array}{c}113 \\
(55.7 \%)\end{array}$ & $\begin{array}{c}35 \\
(17.2 \%)\end{array}$ \\
\hline $\begin{array}{l}\text { 21. Making complaints orally } \\
\text { and in writing. }\end{array}$ & $\begin{array}{c}42 \\
(20.7 \%)\end{array}$ & $\begin{array}{c}124 \\
(61.1 \%)\end{array}$ & $\begin{array}{c}37 \\
(18.2 \%)\end{array}$ \\
\hline $\begin{array}{l}\text { 22. Responding to a complaint } \\
\text { orally and in writing. }\end{array}$ & $\begin{array}{c}62 \\
(30.5 \%)\end{array}$ & $(56.7 \%)$ & \\
\hline
\end{tabular}


There are altogether 22 Skills Specifications for the Language for Interpersonal Use component of the curriculum. From the discussion above, it can be concluded that most of the teachers (72.9\%) perceived that they had recorded medium degrees of implementation for a majority of the Skills Specifications. According to the teachers, the relatively medium degree of implementation among them could be due to their efforts and commitments in overcoming some of the problems that hindered their implementation of the new English language curriculum in their schools. Among the problems were lack of information about the new curriculum, inadequate in-service training and irrelevant teaching materials.

These findings are almost similar to that of Issa Meyes' study (1994) on the Ruralization Program in Mali. His study found that about 70 percent of the teachers perceived their degree of implementation of most of the activities to be of medium level. He attributed this to two reasons. Firstly, Issa Meyes concluded that the teachers' ratings of some of the activities may have been been influenced by their ratings of the other activities as well. Secondly, the relatively medium degree of implementation among the teachers could be due to their efforts and commitments in overcoming some of the problems that hindered their implementation of the Ruralization programme in their schools.

\section{The Inhibiting Factors that had Impeded Teachers' Implementation of the New Curriculum}

Although during the interviews the teachers had quoted various factors that may have inhibited their implementation of the new curriculum, only four factors are highlighted for discussion in this paper. These were factors that had topped the list of inhibiting factors based on the frequency of them being discussed by teachers during the interview sessions.

\section{Too Many Components of the KBSM (Revised) English Language Curriculum}

A majority of the teachers mentioned that there were too many components or aspects of the new KBSM English language curriculum they had to understand and carry out for the whole year. The most outstanding was the three Areas of Language Use. For each of these areas, there are many Skills Specifications to be completed, e.g., the Language for Interpersonal Use alone has 22 Skills Specifications. These skills are in turn divided into several sub-skills to be achieved by students 
by the end of the year. Teachers from Groups B, C and $\mathrm{H}$ also stressed during the interviews that "there were too many activities that had to be carried out with the students for each Skills Specification".

Meanwhile, teachers from Groups A, D and F claimed that the diverse components and aspects of the new curriculum contributed to their inability to carry out more than half of the activities specified in the Huraian Sukatan Pelajaran and the textbook. Some of them confessed that they "needed a lot of time to prepare each lesson carefully because basically the syllabus is new"; and "we had to study and spend many hours trying to understand each language use, the new themes and topics, and also the new activities suggested before carrying them out in the classroom". In fact, many of the teachers interviewed lamented that "due to the diverse components of the new curriculum we had to spend more time preparing each lesson plan than the actual time we take in class to teach the lesson itself".

One of the reasons for the problem faced by teachers could be due to the fact that they were not involved in the early stages of the curriculum development process. This is in line with Fullan's (1991) theory that if teachers were not made aware of the factors that influence their implementation of a new curriculum, then it would negatively affect the extent of their implementation. This would result in teachers' failure to use the products as they were intended to (McNeil, 1977).

A local study by Pandian and Ramiah (2002) also discovered low understanding among teachers having to teach mathematics and science in English. This was because the new curriculums were abruptly introduced, and hence teachers did not play an active role in designing it. Orland-Barak, Kemp, Ben-Or and Levi's study (2004) suggests the possibility of increased success in teachers' implementation of a new curriculum if they were more involved in the early stages. Hannah Danesvari (1995) also found some disparities between the plans of curriculum developers and the actual situations in the classrooms. Her study established that due to many constraints, the teachers' implementation of the former KBSM English Language Curriculum was more focussed on topics related to classroom situations. Therefore they could not pay much attention to the wider contextual issues such as the cultural, economic and historical issues during English lessons. 


\section{Inadequate In-service Training}

The second inhibiting factor faced by the teachers was the lack or inadequacy of in-service training. This was expressed by a majority of the teachers interviewed, who claimed that "the training sessions were not comprehensive", and "were held for short duration of time only". Besides this, some teachers also expressed their views that "the training sessions were not held in proper sequence, i.e., there was no link or follow-up from one training session to the other". Generally, Teachers 1, 2, 3 and 5 stated that although they did attend some training sessions, they "did not comprehend the new curriculum since the training was conducted in isolation from one another", and they "are usually held for a very short period of time, i.e., two or three days only".

The teachers from Groups B, F, and G attributed their failure to comprehend the new curriculum due to the lack of proper planning and organization on the part of the authorities concerned. In fact, one teacher from Group F claimed that "all these deficiencies made the inservice training neither relevant nor adequate to our needs". Surprisingly, almost half of the teachers interviewed claimed that they did not attend any training at all, be it at the national, state, district or even school level. According to some teachers from Group G, they either "received the letter from the JPN only one day before the training session started", or "on the day the training started", and in one case the teacher claimed that she "received the letter after the whole training session was over".

Hence, the lack of training on the teachers' part was another inhibiting factor most often cited by teachers during the interview sessions. Even teachers who had attended some training saw it as an inhibiting factor, particularly because it was still not sufficient for them to get a good grasp of the new components in the curriculum. On top of that, the lack of proper planning and organization of the training sessions made them less effective to the teachers. The importance of training was also expressed by Goodlad (1979) since it would ensure that the teachers could use the products as set by the authorities in their respective schools. Lack of it would mean teachers would not have clear ideas as to what need to be done.

Noor Azmi (1988) found an inhibiting factor similar to that of this study, i.e. the inadequate training and teaching materials that greatly impeded the teachers' work. His findings are almost similar to the ones of this present study, since many teachers in this study also felt that they lacked proper guidance and supervision due to 
poor organization of the in-service training by the authorities concerned. As such, many of the teachers he interviewed claimed that they had to make use of their seniority in terms of age and experience in teaching English in secondary schools to ensure effective implementation of the new curriculum.

Agrawal's study (2004) provides almost similar findings to those of this study. Teachers in New Delhi were required to attend the Communicative English Language Teaching Orientation Courses to familiarize them with the new curriculum. However it was discovered not only was the in-service training provided limited in number but they were also not made available to every teacher. So the courses were not significant in helping teachers understand the new curriculum and the new approach to teaching English, and hence failed in improving their capabilities and performance in the classroom.

\section{Time Constraints}

Many of the teachers interviewed agreed that time constraint was indeed an inhibiting factor to them. According to them (Groups A, C, D, F and G), they had "too many other roles and duties to perform besides teaching". Among other things, they also had to do a lot of paper or clerical work such as prepare test and exam questions, mark students' work and exam scripts, collect students' fees etc. According to Teacher 1, all these extra duties had "either directly or indirectly affected our implementation of the new curriculum in the class". On top of that, Teachers 3 and 6 claimed that they were "also responsible for the preparation and administration of exams, tests, quizzes etc. both in the classrooms and at the school level". The situation was worsened by the big class sizes they had to cope up with. Many of them claimed they had an average total of 40 to 45 students in each class. This has "posed a serious problem for teachers since class control was difficult, and organizing the students to participate in the activities was very time-consuming".

Related to the time constraint issue was the number of English lessons the teachers had to teach in a week. Many of them had 20 or more periods of English per week. Teachers 2, 4, 5, and 7 generally agreed that "preparing the lessons was problematic and timeconsuming" for them. This was because they could not use the same exercises or teaching materials in all the four or five classes because of 
the students' different levels of proficiency and interest in the subject matter. In fact, teachers from Groups C, F and G commented that most of the time they had to "prepare slightly different exercises or activities even among the students in the same class, to cater to their different levels of proficiency in English language". This was also necessary to avoid boredom and lack of motivation among the less proficient students as well as to provide a challenge for the better ones. Many of the teachers interviewed claimed that "all these additional tasks had impeded their ability to fully carry out all the activities of the new curriculum".

Based on the discussion above, it can be concluded that another often-quoted inhibiting factor by the teachers was time constraint, which according to them led to their inability to carry out all the activities specified in each Skills Specification. The main problem was that teachers were expected to carry out various activities for the different Skills Specifications, which required a lot of efforts, preparation and time on their part. As such, they could not implement most of the activities listed in the Skills Specifications of the new English language curriculum.

Some of the teachers interviewed in this study said that many of them had too many other duties and work to carry out besides teaching. Furthermore, some of them who had to teach many classes of English (20 to 25 periods per week) found that it was a hindering factor for them, particularly in terms of preparing suitable lessons and materials for each class. An almost similar finding as this was made by Suaidi Haji Otek (1995) in his study on teachers' implementation of the KBSR. He found that many teachers had complained that they were expected to do too much in the curriculum. On top of that, they also had to cope up with other extra-curricular activities and over-sized classes.

\section{Inadequate and Irrelevant Teaching Materials}

A majority of the teachers also felt that the irrelevant and inadequate teaching materials were the other inhibiting factors for their effective implementation of the new curriculum. Almost all of them confessed that they "needed more teaching materials, not only in terms of quantity but also quality". One problem faced by quite many teachers (Groups B, D, E, F and G) was the lack of suitable or relevant teaching materials, especially "in the form of grammar exercises, reading passages, listening texts and suggestions for class activities". 
Another problem related to this was the inadequate types of teaching materials provided, whereby about one-third of the teachers wanted "other materials besides the textbook and the HSP". Many of them expressed their wish for "students' workbook, a detailed scheme of work, audio-visual materials and some types of computer software for use in the classroom". Some of the teachers (Teachers 2, 3 and 6) also explained that they were dissatisfied because some materials were only provided for certain teachers but not for others. An example was the Europlus software, which was not made available to all teachers, especially those from rural schools.

The final inhibiting factor highlighted in this study was the lack of relevant and adequate teaching materials which were said to pose serious problems to the teachers. These teaching materials were described as either not up to the students' proficiency level, not interesting, or not sufficient for teachers' use in the classroom. The only material found to be helpful by most of the teachers was the textbook that accompanied the new curriculum. As such, the teachers suggested for more and relevant materials be made available to them. These included computer software, suitable reading passages, workbooks, taperecorded materials, reading passages, and teaching aids such as cassettes, diskettes etc. (However, it should be noted that some of these materials may have been made available to teachers since this study was conducted).

\section{CONCLUSION}

Several conclusions can be made based on the findings of this study. Firstly, there were several factors that had impeded teachers' implementation of the new curriculum. They were time constraint, the students' proficiency level and attitude towards English, the teaching materials and in-service training they received, and the big class sizes and number of teaching periods. It should be noted that some factors such as the in-service training and teaching materials functioned as both facilitating and inhibiting factors for the teachers.

The findings presented in this paper would hopefully serve as significant contributions to increase the literature in the implementation of curriculum changes in the Malaysian classrooms. Firstly, they would function as guidelines for several groups of people involved in the teaching and learning of English language, such as teachers, students, 
the Jurulatih Utama (JUs) and parents. Secondly, it is hoped that they would provide some useful insights to the authorities concerned as to which aspects of the new Form Four English language curriculum that need to be analyzed and improvised. These would ultimately not only improve teachers' degree of implementation of the new syllabus, but also help increase students' interest to learn the language and also improve their proficiency in it.

\section{REFERENCES}

Adamson, B. (2003). China's official English: The Curriculum for junior secondary schools since 1949. Humanising language teaching, year 5, issue 3 .

Agrawal, M. (2004). Curricular reforms in schools: The importance of evaluation. Journal of curriculum studies, 37, pp. 361 - 379.

Anna Christina Abdullah. (1989). Kepercayaan guru terbadap peranan mereka dalam proses perkembangan kurikulum. Unpublished M.Ed. dissertation, Universiti Sains Malaysia.

Borg, W.R.and Gall, M.D. (2002). Education research: An introduction. ( $5^{\text {the }}$ d.). New York: Longman.

Cheng, Yin Cheong. (1994). Effectiveness of curriculum change in schools. The international journal of educational management, 8 , issue 3 .

Fullan, M. (1982). The meaning of educational change. New York: Teachers College Press.

Fullan, M. (1991). The new meaning of educational change. New York: Teachers College Press.

Fullan, M. (2000). The three stories of education reform. Kappan Professional Journal 2000, 81, pp. 581-584.

Goodlad, J.I. (1979). Curriculum inquiry. New York: McGraw Hill.

Hannah Danesvari, P. (1995). Fragments of a vision: A case study of the implementation of an English language curriculum programme in five Malaysian secondary schools. Doctoral thesis, University of East Anglia.

Issa Meyes, C. (1994). Ruralization of Malian fundamental education:The relationship between its degree of implementation and teachers' perceptions. Unpublished doctoral dissertation. Universiti Sains Malaysia. 
Kementerian Pendidikan Malaysia. (2002). Sukatan Pelajaran Kurikulum Bersepadu Sekolah Menengah. Kuala Lumpur: Pusat Perkembangan Kurikulum.

Kementerian Pendidikan Malaysia. (2003). Huraian sukatan pelajaran, kurikulum bersepadu Bahasa Inggeris Tingkatan Empat. Kuala Lumpur: Pusat Perkembangan Kurikulum.

Khatijah Khalid. (1989). Curriculum change and innovation: A study in the teaching of secondary school Geography in Malaysia. Unpublished doctoral dissertation, United Kingdom.

Mc Neil, J.D. (1977). Curriculum : A comprehensive introduction. Boston: Little, Brown and Company.

Merriam, S.B. (1990). Case study research in education. A qualitative approach. California: Jossey-Bass Inc., Publishers.

Neuman, W.L. (1997). Social research methods: Qualitative and quantitative approaches. Boston: Allyn and Bacon.

Noor Azmi Ibrahim. (1988). In-service courses and teachers' professionality: The implementation of KBSR in Malaysia. Unpublished doctoral dissertation, University of Sussex, U.K.

Orland-Barak, L., Kemp, J., Ben-Or, T. \& Levi, Z. (2004). Seeing the 'New' in light of the 'Old': Evolving interpretations of a new national English curriculum. Journal of Curriculum Studies, 36, pp. $321-339$.

Pandian, A. \& Ramiah, R. (2002). Mathematics and Science in English: Teacher voice. The English Teacher, 33, pp. 50 - 61.

Punitha Vathy, K. (1998). Kajian tentang keprihatinan guru dalam pelaksanaan kurikulum prinsip akaun sekolah menengah. Unpublished M.Ed. dissertation, Universiti Malaya.

Rajaretnam, T. and Nalliah, M. (1999). The bistory of English language teaching in Malaysia. Shah Alam: Institut Teknologi MARA.

Solomon, J.S. (1988). The development of bilingual education in Malaysia. Petaling Jaya; Pelanduk Publications.

Suaidi Bin Haji Otek. (1995). Kurikulum baru sekolah rendah : An analysis of the experience of teachers in a primary school in Sarawak, Malaysia. Unpublished M.Ed. dissertation, London University of Newcastle.

Tengku Zawawi Tengku Zainal. (2004). Penggunaan internet dalam pendidikan Matematik. Jurnal Penyelidikan 2004, Jilid III, Jabatan $\mathrm{R} \& \mathrm{D}, \mathrm{MPKTBR}$. 


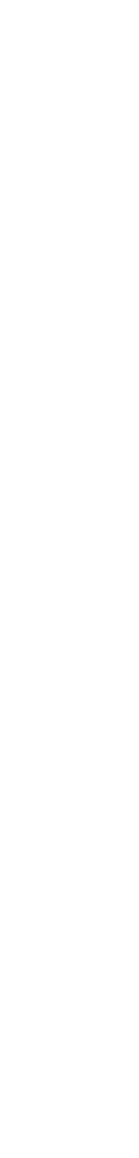

